\title{
Strategies for creating new venture legitimacy
}

\author{
Tomas Karlsson and Karen Williams Middleton
}

\begin{abstract}
New ventures, being heavily subjected to liabilities of newness, are seen to engage in legitimacy strategies to overcome these liabilities. Building on an adapted theoretical framework of organizational legitimacy, self-reported weekly diaries of twelve entrepreneurs were analysed to identify strategies used by new ventures to create legitimacy. New ventures appear to prefer pragmatically related strategies over moral and cognitive ones, and adopt malleability with respect to moral strategies. The novelty of the venture technology increases the focus on conformity strategies, whereas more established technologies use manipulative strategies to gain legitimacy. New ventures also appear to engage strongly in moral selection strategies in terms of goal formulation.
\end{abstract}

\section{Keywords: institutional theory; legitimacy; new venture creation; strategy}

Tomas Karlsson and Karen Williams Middleton are equal first authors of this article. They are with the Division of Management of Organizational Renewal and Entrepreneurship, Chalmers University of Technology, 41296 Gothenburg, Sweden. Corresponding author: Karen Williams Middleton. E-mail: karen.williams@chalmers.se.

Legitimacy, according to Suchman, is 'a generalized perception or assumption that the actions of an entity are desirable, proper or appropriate within some socially constructed system of norms, values, beliefs and definitions' (Suchman, 1995, p 574). The concept of legitimacy has been applied primarily to understanding established organizations; for such organizations, strategies focus on maintaining and repairing legitimacy in order to be judged as desirable and necessary to key stakeholders and society in general (Suchman, 1995). Emerging organizations, such as new ventures, do not possess established legitimacy to defend and/or manage, and instead chiefly engage in strategies to build legitimacy.

In this article, we focus on the newest of the new: nascent ventures. We define nascent ventures as operating in the stage prior to initial legal registration and/or first annual reporting. These are ventures in the process of emergence, such that they are not yet established organizations (Davidsson, 2006). Their founders are often engaging in a venture creation process for the first time and, as such, lack entrepreneurial expertise, which is gained through experiential learning (Politis, 2008; Sarasvathy, 2008). Nascent ventures are heavily subject to the liabilities of newness (Stinchcombe, 1965), in at least two respects. First, they may have an invention that needs to gain acceptance in the market. Engaging in creating a new market around a new technology is problematic from an institutional perspective, because the new venture is required to engage in legitimizing both the technology and the organization at the same time (Aldrich and Fiol, 1994). Second, during the process of emergence new ventures are also often exceptionally resource constrained. This can leave new ventures desperately searching for significant and, often, scarce external financing, thus positioning them as having significant liabilities of newness (Freeman et al, 1983; Shepherd et al, 2000; Stinchcombe, 1965).

As a result, new ventures often choose one of two main approaches to create legitimacy and overcome the liabilities of newness. One is to build legitimacy as an 
organization - that is, the legal object, often represented by a company name, brand or new product. In this approach, external legitimacy through institutional support is often more critical than internal strategies (Singh et al, 1986). The other approach is to transfer the personal legitimacy of the venture founders and owners to the new venture and, with regard to this approach, research has focused on the criticality of human and social capital (Anderson et al, 2007; De Clercq and Voronov, 2009; Mosey and Wright, 2007). In the application of either approach, new ventures (and their founders) are challenged with balancing a sense of distinctiveness with a sense of belonging (Shepherd and Haynie, 2009) common to the entrepreneurial phenomenon.

New ventures are understood to create legitimacy in the same way as established organizations, through adopting moral, pragmatic and cognitive types of legitimacy (Aldrich and Ruef, 2006; Drori and Honig, 2013; Suchman, 1995; Zimmerman and Zeitz, 2002). However, given the importance of creating legitimacy during emergence of the venture, including overcoming liabilities of newness, scholarship has generally overlooked how legitimacy develops in new ventures (Drori and Honig, 2013), with few empirical investigations offered.

The purpose of this article is to explore the strategies used by new ventures to create initial legitimacy and overcome their liabilities of newness. We contribute to existing research by investigating, empirically, legitimacy-creating strategies and thus improving understanding of the consequences of such strategies. As a result, we are able to develop empirically based recommendations that contribute to the development of new venture creation policies and support.

\section{Theoretical frame of reference}

The study of legitimacy encompasses how legitimacy is built, maintained and repaired if lost (Suchman, 1995). In this article, we focus on how legitimacy is built in new ventures. The focus on creation of legitimacy is a natural choice because new ventures have little, if any, to maintain or lose. Rather, new ventures must gain initial acceptance for their organization among different stakeholders - a situation which established organizations already enjoy. Specific liabilities of newness suggest that new ventures are at a disadvantage relative to incumbents, because the new venture needs to establish trust and functional exchanges with a number of actors - such as suppliers, new employees and customers. In the case of an established product or industry, the new venture needs to develop an efficient production or transformational process, allowing it to be
Table 1. Legitimacy definitions.

\begin{tabular}{|c|c|c|}
\hline Concept & Definition & Conceptual example \\
\hline Pragmatic & $\begin{array}{l}\text { Legitimacy gained } \\
\text { from the self-interest } \\
\text { of an organization's } \\
\text { immediate audience. }\end{array}$ & $\begin{array}{l}\text { Extraordinary product } \\
\text { performance, cost } \\
\text { savings, risk } \\
\text { reduction, problem } \\
\text { solving. }\end{array}$ \\
\hline Moral & $\begin{array}{l}\text { Legitimacy gained } \\
\text { from perceptions of } \\
\text { just and correct } \\
\text { procedures and } \\
\text { certifications, and } \\
\text { characters of leaders. }\end{array}$ & $\begin{array}{l}\text { Correct sequencing o } \\
\text { actions, adhering to } \\
\text { business norms; for } \\
\text { example, business } \\
\text { planning, visions, } \\
\text { business models. }\end{array}$ \\
\hline Cognitive & $\begin{array}{l}\text { Legitimacy gained } \\
\text { from tacit mimicry of } \\
\text { the environment by } \\
\text { acting as expected } \\
\text { and in taken-for- } \\
\text { granted ways. }\end{array}$ & $\begin{array}{l}\text { Degree of cultural } \\
\text { closeness, } \\
\text { comprehensibility, } \\
\text { communicative ability. }\end{array}$ \\
\hline
\end{tabular}

competitive in relation to others in the same market. In the case of new technology, the new venture needs to cope with the costs of technology development and communicating the benefits of the new product or service (Aldrich and Fiol, 1994; Cornelissen and Clarke, 2010; Starr and MacMillan, 1990).

Due to their liabilities of newness, there is an added need for new ventures (and their founders) to build trust because, de facto, they are operating in a situation with no prior track record (Shepherd et al, 2000). Larson and Starr (1993) described the importance of social networks, especially in the emergent stage of an entrepreneurial venture. This has caused researchers to look more carefully at the role of symbolic strategies for creating legitimacy, through the use of, for example, narratives or metaphorical reasoning (Cornelissen and Clarke, 2010; Drori and Honig, 2013; Landau et al, 2014; Lounsbury and Glynn, 2001; Suddaby and Royston, 2005; Williams Middleton, 2013; Zott and Huy, 2007).

The literature essentially distinguishes between three different types of legitimacy, which Suchman (1995) categorizes as pragmatic, moral and cognitive (see Table 1). These relate roughly to the main pillars of institutional theory (Scott, 2014) and the isomorphic pressures creating conformity among organizations (DiMaggio and Powell, 1983). Given the strong link between conformity and legitimacy, it is usual for legitimacy to be awarded to those who conform to institutional pressures (Barreto and Baden-Fuller, 2006; DiMaggio and Powell, 1983). Acting in line with institutional assumptions or perceptions can be seen as a commonly-adopted strategy to pursue in order to gain 
Table 2. Legitimacy strategies.

$\begin{array}{ll}\text { Concept } & \text { Definition } \\ \text { Conform } & \text { Actions taken by a firm to comply with and acquiesce to } \\ & \text { institutional pressures. }\end{array}$

Select

Manipulate

\begin{abstract}
Encompasses strategies to reduce the extent to which conformity is necessary, either by selecting partial compliance or symbolic compliance or selecting an industry with matching institutional pressures.
\end{abstract}

An active response in which the institution or organization is actively trying to alter the environment.

\section{Conceptual example}

Behaviours, plans and talks to conform to the institutional pressure to write business plans will be coded here. Copying role models, adopting behaviour according to business planning literature and compliance with rules.

Renegotiation, change of industry, concealing.

Open dissent, converting constituents, evangelizing, lobbying. legitimacy (Meyer and Rowan, 1977; Suchman, 1995). Furthermore, some institutional pressures can be so strong and taken for granted that not conforming to them is unthinkable to most actors. However, research from the entrepreneurship domain provides empirical evidence suggesting that the actions taken by new ventures may be more important in establishing legitimacy than conforming to institutional expectations (Tornikoski and Newbert, 2007). To fit the premise of 'entrepreneurial', new ventures need to illustrate distinctiveness while also establishing a sense that they belong to a community or collective social understanding (Clarke, 2011; Donnellon et al, 2014; Navis and Glynn, 2011; Shepherd and Haynie, 2009). New ventures have been shown to apply different strategies for creating legitimacy, ranging from conforming to rebelling and innovating (Oliver, 1991; Suchman, 1995; Zimmerman and Zeitz, 2002).

In the following sections we start by describing the three basic types of legitimacy, as presented by Suchman (1995), and then discuss three types of strategies organizations can adopt to address these different types of legitimacy. Following this we present legitimacy strategies (summarized in Table 2), again based on the work by Suchman (1995) and also including strategies designed for dealing with institutional pressures.

\section{Types of legitimacy}

Pragmatic legitimacy is granted on the basis of the self-interest of organizational stakeholders. It is important for new ventures because it does not necessarily rely on convention but, rather, on self-interested calculations. Pragmatic legitimacy is about providing what stakeholders need, such as a product, service or some symbolic currency. It is essentially a function of what the new venture can offer in the marketplace, which is normally assumed to be the most important function an organization must fulfil.
However, focusing on pragmatic legitimacy alone, in the absence of also employing minimum levels of other types of legitimacy, is regarded as insufficient for new ventures (Suchman, 1995; Zimmerman and Zeitz, 2002).

Moral legitimacy is based on the judgment of whether an activity is the 'right thing to do'. Determining that judgement can be explored through qualifying questions, such as:

- Is this done according to the correct procedures and protocols?;

- Is this person likeable - do they and/or the business share my values and perspectives?; and

- Is the business model written according to publicly acknowledged literature, and does it represent the creation of value for others?

By establishing straightforward and transparent routines and formalized requirements, titles and professional codes of conduct, new organizations can gain moral legitimacy. However, attaining moral legitimacy can be costly and thus it can be a major challenge for new ventures, which are often resource constrained.

Cognitive legitimacy is perhaps the most influential type of legitimacy, but also the most difficult to define. Cognitive legitimacy is commonly referred to as 'taken for granted-ness', which refers to situations in which alternatives are virtually unthinkable. Because they are unthinkable, it is impossible to provide an example; but the existence of the Internet, and cost-free air, could be examples of things which are difficult to think away. Another aspect of cognitive legitimacy that is easier to analyse is comprehensibility: the extent to which it is possible to understand what the new venture is about. Cornelissen and Clarke (2010) suggest, for example, that the more comprehensible (through metaphor and 
analogy) a new venture can be about its radical innovation, the more legitimate it will become. For the new venture this means that in practice the underlying 'invention' needs to be coupled with understandability. Even if the invention departs radically from existing solutions, the new venture needs to translate and transform the invention such that it feels familiar to the customer. For example, one reason for the success of Edison's lightbulbs in the latter part of the 19th century was that they emitted soft warm light, reminiscent of candles and oil lamps. Other experiments with electric light failed commercially because people perceived the cold white light they emitted as unnatural (Hargadon and Douglas, 2001).

Individuals use these different types of legitimacy to make an impact on their surroundings, which requires human agency, and take strategic action aimed at achieving that which they are attempting to build or change. New ventures must determine which type of legitimacy is appropriate relative to both their existing or desired stakeholders and to whether they are seeking to represent adherence and belonging or independence and distinctiveness (Shepherd and Haynie, 2009). Table 1 provides conceptual examples for the types of legitimacy specific to the nascent phase of development in venture creation.

\section{Legitimacy strategies}

Institutional theory is traditionally concerned primarily with pressures that make organizations increasingly similar. DiMaggio and Powell (1983) conceptualized institutional theory as a structural, almost inescapable iron cage of isomorphic force. Attention to strategies in relation to institutional pressures is partially contradictory to this structurally determined version of institutional theory. However, institutional pressures exerted on organizations are rarely complete. There is limited enforcing of institutional rules and norms, and there is a time lag between inconsistency with institutional pressures and enforcement. Furthermore, the different institutional pressures exerted are sometimes conflicting: for example, owners want to maximize return on investment, while the state wants to generate tax revenue. Different industries have different norms and rules and new ventures can tailor their business model to adopt such norms or rules to suit their purpose. For example, a new venture can choose to circumvent FDA regulation by implementing a new technology as a consultancy business or device rather than a new drug or medical treatment. These gaps in isomorphic forces, paradoxes and multiplicity allow for institutional strategies. We have chosen to focus on the three broad types of strategies suggested by Suchman (1995); conform, select and manipulate (see Table 2).

Conforming strategies are adopted by a firm to comply with and acquiesce to institutional pressures. As noted earlier, institutional theory explicitly emphasizes conformity over other ways of creating legitimacy (DiMaggio and Powell, 1983). New ventures are often advised to use conforming strategies to overcome the liabilities of newness (Aldrich and Fiol, 1994; Stinchcombe, 1965). It is normally assumed that, in general, organizations conform to institutional pressures and, given the resource constraints and the liabilities of newness, conforming to institutional pressures may be the only option. However, conformity can also be very costly. For example, for a café there may be significant costs in adhering to the statuary obligations concerning location, labour, health and food safety, and accounting and tax. For a new biotech venture, the average cost of adhering to drug safety regulations has been estimated to amount to some US\$1.3 billion (Feyman, 2014).

Selection strategies reduce the extent to which conformity is necessary, either by selecting partial or symbolic compliance or selecting an industry that has matching institutional pressures. Selection strategies often involve adhering to institutional pressures but exerting influence regarding which to adapt to - for example, selecting the customer segment to target or in which industry to act, or choosing to please the owners at the expense of conforming to tax laws. Selection can also involve suppressing non-conformity, either by using symbolic conformity or simply by not informing others about the real aim and actions of the organization. Due to the costs of conformance strategies, new ventures often need to use other legitimacy strategies to sustain themselves in the marketplace. They might consider another type of industry to enter; for example, selecting to position the venture in the medical-technology industry instead of the drug industry. Alternatively, the venture may choose to conform only symbolically; for example, a café with long procedural protocols regarding employee training on cleanliness and health safety might skip such routines when there are lots of customers waiting to be served.

Manipulation strategies involve active engagement in trying to change an institution or alter the surrounding environment. Manipulation is normally seen as a strategy for the largest companies, which may be capable of influencing legislature (often through lobbying). This can make both entry into the industry sector, for new ventures or smaller competing organizations, and/or setting new industry standards for 
Table 3. Conceptual framework of new venture legitimacy strategies.

$\begin{array}{ll}\begin{array}{l}\text { Conceptual coding category } \\ \text { Pragmatic-Conform }\end{array} & \begin{array}{l}\text { Conceptual example } \\ \text { Conforming to customer } \\ \text { demands/capital demands } \\ \text { Pragmatic-Select }\end{array} \\ \begin{array}{l}\text { Selecting input-throughput- } \\ \text { market, based on technology/ } \\ \text { product match }\end{array} \\ \text { Pragmatic-Manipulate } & \begin{array}{l}\text { Marketing of product benefits } \\ \text { Moral-Conform }\end{array} \\ \text { Moral-Select } & \text { Define goals } \\ \text { Moral-Manipulate } & \text { Convince or proselytize } \\ \text { Cognitive-Conform } & \text { Mimic standards } \\ \text { Cognitive-Select } & \text { Seek certification } \\ \text { Cognitive-Manipulate } & \text { Spread new models }\end{array}$

acceptable action and behaviour, more difficult. Manipulation is normally understood as a high cost strategy. Because institutions are cultural and societally related functions, manipulative strategies require the use of time and significant resources if they are to have any impact. Given that new ventures often suffer resource constraints, manipulation strategies are usually less commonplace among new ventures, although examples do exist (see the Pirate Bay example in Palmås and Von Busch, 2006). On a micro level, manipulation strategies can be understood as influencing people's mindsets around established norms and could thus be more frequent at this level than on a macro level.

The types of legitimacy and legitimacy strategies outlined in Tables 1 and 2 are combined in Table 3, which summarizes nine legitimacy strategies that could be used by new ventures when engaging in the creation of legitimacy. For each of the nine strategies, a conceptual example is provided: these conceptual examples act as theory-driven codes applied during empirical analysis, as discussed in the following section.

\section{Methodology}

In order to address appropriately the dynamic nature of newness as well as the process aspects of legitimacy creation, we chose a real-time, longitudinal, qualitative methodology based on weekly diary data. Diary data are uncommon in entrepreneurship research (Ohly et al, 2010), although they are more commonly used in other fields (Bolger et al, 2003; Stone and Shiffman, 2002). Diaries offer frequent and current information of daily or weekly events and experiences and as such they capture changing decisions, perceptions and opinions over time and events in ways that are not possible when using, for example, cross sectional designs (Bolger et al, 2003). Equally, patterns from diary observations may well differ significantly from studies over longer time intervals (Zaheer et al, 1999). Although entrepreneurial endeavours are inherently unpredictable and uncertain, retrospective stories of successful entrepreneurs abound in which, in hindsight, the entrepreneur's agency is heroic and appears to be quite easy. Diaries overcome or reduce this risk of retrospective and success bias, both of which are major concerns when studying entrepreneurs (Bird et al, 2012; Cassar and Craig, 2009).

\section{Case descriptions}

A complete description of the four cases used in the current analysis is presented in Appendix A. The cases represent the more complex (multiple members) and robust (frequency and depth of diary entries) examples from the 2009-2010 cohort, and are also representative of the cultural diversity of the entire cohort and include 3 female and 9 male participants.

During the 20 weeks of the venturing programme the prospective entrepreneurs engaged in venture creation activities were asked to write a weekly diary. This was introduced before the 20 week period and submitting it was encouraged rather than compulsory. Each diary entry was submitted weekly by e-mail to the manager of the training programme. The guidelines were that the entrepreneurs should report what they did during the week; with whom they met; why they did what they did; and overall reflections of what they learned during the week. The original purpose was to enable the participants to reflect on their behaviour and develop their ability to monitor and adjust their behaviour and improve their metacognitive skills (Haynie et al, 2012). In effect the diaries thus constituted secondary data and the quality of the data was improved as the process reduced the risk of their being skewed into any of the researchers' preferences.

Individual diary entries varied in length from roughly half a page to two pages. Because it was important for us to understand the network creation process over time, we chose to include only diaries for cases - consisting of individual or team ventures - in which at least 10 weeks were covered. Our analysis involved coding (theory-driven and empirically-driven) as well as abstraction consisting of longitudinal description and interpretation. The theory-driven codes were based on the nine different categories suggested by our framework of the three legitimacy types and the three strategies. The representative quotations presented in Table 4 are drawn from four cases selected for study.

For each of the nine legitimacy strategies, an empirical quotation is provided, illustrating the type of 
Table 4. Empirical examples of new venture legitimacy strategies.

\begin{tabular}{|c|c|c|}
\hline $\begin{array}{l}\text { Conceptual coding } \\
\text { category }\end{array}$ & Conceptual example & Empirical example of legitimacy strategy \\
\hline Pragmatic-Conform & $\begin{array}{l}\text { Conforming to customer } \\
\text { demands/capital } \\
\text { demands }\end{array}$ & $\begin{array}{l}\text { 'We must alter our approach depending on what kind of investor we are } \\
\text { approaching. For VCs and business angels, it is all about the entrepreneurial } \\
\text { team and their perceived value with the venture. For the government agencies } \\
\text { like ALMI, it is all about having a solid and thorough business plan for the right } \\
\text { geographical location.' (Mac, 20091218) }\end{array}$ \\
\hline Pragmatic-Select & $\begin{array}{l}\text { Selecting input- } \\
\text { throughput-market, } \\
\text { based on technology/ } \\
\text { product match }\end{array}$ & $\begin{array}{l}\text { 'Winning Venture Cup Syd was a fantastic accomplishment. Since winning, } \\
\text { however, our main focus has been on the business rather than the plan. This } \\
\text { meant identifying critical activities which need to get done in order to prepare } \\
\text { our business to enter sales relationships with OEMs.' (Burt, 20100515) }\end{array}$ \\
\hline Pragmatic-Manipulate & $\begin{array}{l}\text { Marketing of product } \\
\text { benefits }\end{array}$ & $\begin{array}{l}\text { 'I suppose the desired outcome of this event was to raise brand awareness } \\
\text { and I firmly believe we did that.' (Matt, 20100319) }\end{array}$ \\
\hline Moral-Conform & Align with morals & $\begin{array}{l}\text { 'We decided to set up a meeting with Thomas Rundqvist to sort out the details } \\
\text { of the IPR contract with Toyota: we believed that the product has great } \\
\text { potential, especially with the legislation changes such as EU2020 and EU } \\
2030 \text { which imply that the carbon dioxide levels must drop by } 20 \text { tons to } 2020 \\
\text { and } 30 \text { tons to 2030.' (Mac, 20100129). }\end{array}$ \\
\hline Moral-Select & Define goals & $\begin{array}{l}\text { 'We are driven by the goal to make a sale before the end of the academic term } \\
\text { and this partnership will greatly increase the likelihood of that happening.' } \\
\text { (Jim, 20100409) }\end{array}$ \\
\hline Moral-Manipulate & Convince or proselytize & $\begin{array}{l}\text { 'We had to convince the researchers that owning less equity is better and } \\
\text { more favourable than having more. We managed to lay out a very convincing } \\
\text { strategy and get them on our side.' (Tony, 20100430) }\end{array}$ \\
\hline Cognitive-Conform & Mimic standards & $\begin{array}{l}\text { 'America has done that, Sweden has done that, and the idol storm has been in } \\
\text { China for last } 3 \text { years. Why couldn't we apply this system into the jewelry } \\
\text { industry?' (Charlotte, 20100205) }\end{array}$ \\
\hline Cognitive-Select & Seek certification & $\begin{array}{l}\text { 'They approved our napkin campaign, but they are waiting on the actual funds } \\
\text { to come in from Regional Skane, which is exciting to have an organization like } \\
\text { that approve of our service.' (Tom, 20100319) }\end{array}$ \\
\hline Cognitive-Manipulate & Spread new models & $\begin{array}{l}\text { 'Companies early in the value chain don't see a need for our algorithm unless } \\
\text { someone further down the value chain is demanding the enhancement.' (Mac, } \\
\text { 20100122) }\end{array}$ \\
\hline
\end{tabular}

sentences coded in each category. All learning journals pertaining to each of the cases were analysed within this framework. Tables 5, 6 and 7 provide the baseline counts of instances of each of the nine codes.

\section{Findings and discussion}

The article advances the literature by identifying strategies through which new ventures (and their 'entrepreneurs') create legitimacy. The frequency of the application of each type is represented in tables for each case, illustrating both individual totals and team totals.

For Image Enhancement, the most common strategy for legitimization was pragmatic. It is interesting to observe that conforming strategies are those most commonly adopted by the participants, not only in this case but also in all the cases. Burt and Tony stand out from many of the other participants in their tendency to use moral-manipulative means of legitimization. Music Training (Table 6) illustrates a similar pattern to Image Enhancement, adopting an even stronger pragmatic strategy for legitimization, followed by generally equal moral and cognitive strategies.

In the case of Jewelry Design (Table 7), Jenny applied the moral-select strategy more than any of the other specific categories, which is uncommon across the four cases. Many of the statements concern goal definition and are presented in simplistic and concise phases in the diary entries. Even so, the broad strategy applied by Jenny is consistent with that of all the other participants. Both Charlotte and Maria followed the more common profile of either pragmatic-conform or pragmatic-select as the frequent specific category, and generally applied pragmatic legitimacy.

Another pattern emerging is the rarity of manipulative strategies. In the case of Jewelry Design 
Table 5. Image Enhancement case.

\begin{tabular}{lcccc}
\hline & Burt & Mac & Tony & $\begin{array}{c}\text { Total per } \\
\text { category }\end{array}$ \\
Pragmatic-Conform & 5 & 2 & 4 & 11 \\
Pragmatic-Select & 2 & 3 & 4 & 9 \\
Pragmatic-Manipulate & 4 & 0 & 3 & 7 \\
Total Pragmatic & 11 & 5 & 11 & 27 \\
Moral-Conform & 0 & 0 & 4 & 4 \\
Moral-Select & 5 & 0 & 3 & 8 \\
Moral-Manipulate & 5 & 0 & 2 & 7 \\
Total Moral & 10 & 0 & 9 & 19 \\
Cognitive-Conform & 4 & 2 & 4 & 10 \\
Cognitive-Select & 0 & 0 & 2 & 2 \\
Cognitive-Manipulate & 0 & 1 & 1 & 2 \\
Total Cognitive & 4 & 3 & 7 & 14 \\
\hline
\end{tabular}

Table 6. Music Training case.

\begin{tabular}{lrrrr}
\hline & Matt & Ron & Sean & $\begin{array}{c}\text { Total per } \\
\text { category }\end{array}$ \\
Pragmatic-Conform & 5 & 5 & 4 & 14 \\
Pragmatic-Select & 2 & 4 & 5 & 11 \\
Pragmatic-Manipulate & 4 & 3 & 1 & 8 \\
Total Pragmatic & 11 & 12 & 10 & 33 \\
Moral-Conform & 2 & 2 & 2 & 6 \\
Moral-Select & 1 & 4 & 4 & 9 \\
Moral-Manipulate & 0 & 0 & 0 & 0 \\
Total Moral & 3 & 6 & 6 & 15 \\
Cognitive-Conform & 0 & 2 & 5 & 7 \\
Cognitive-Select & 3 & 2 & 1 & 6 \\
Cognitive-Manipulate & 0 & 0 & 0 & 0 \\
Total Cognitive & 3 & 4 & 6 & 13 \\
\hline
\end{tabular}

(Table 7), both Maria and Jenny had a moral stance as the second strongest strategy applied, though still only using conforming and selective strategies. Applying a manipulative strategy is the least common, in comparison to conforming and selective. The Napkin Ads case (Table 8) also tended primarily to use conforming and selective strategies, but equally demonstrates a significant amount of manipulative strategy, particularly within the pragmatic typology. As in the Image Enhancement case, two of the actors are atypical in applying a moral-manipulative strategy. Tom, like Tony, is also unusual in that he also used a greater amount of cognitive-type strategizing for legitimization than many of the other participants.

Table 9 summarizes the overall legitimacy activities among the four cases over the 20 week period. There is variation, but some overall tendencies can be identified. The dominant type of legitimacy invoked was pragmatic. A clear focus of all the new ventures is to
Table 7. Jewelry Design case.

\begin{tabular}{lcccc}
\hline & Charlotte & Jenny & Maria & $\begin{array}{c}\text { Total per } \\
\text { category }\end{array}$ \\
Pragmatic-Conform & 8 & 3 & 6 & 17 \\
Pragmatic-Select & 4 & 2 & 9 & 15 \\
Pragmatic-Manipulate & 3 & 2 & 4 & 9 \\
Total Pragmatic & 15 & 7 & 19 & 41 \\
Moral-Conform & 1 & 0 & 1 & 2 \\
Moral-Select & 3 & 4 & 8 & 15 \\
Moral-Manipulate & 0 & 0 & 0 & 0 \\
Total Moral & 4 & 4 & 9 & 17 \\
Cognitive-Conform & 5 & 1 & 3 & 9 \\
Cognitive-Select & 1 & 1 & 2 & 4 \\
Cognitive-Manipulate & 0 & 0 & 0 & 0 \\
Total Cognitive & 6 & 2 & 5 & 13 \\
\hline
\end{tabular}

Table 8. Napkin Ads case.

\begin{tabular}{lcccc}
\hline & Jim & Saul & Tom & $\begin{array}{c}\text { Total per } \\
\text { category }\end{array}$ \\
Pragmatic-Conform & 1 & 2 & 6 & 9 \\
Pragmatic-Select & 4 & 2 & 4 & 10 \\
Pragmatic-Manipulate & 6 & 4 & 3 & 13 \\
Total Pragmatic & 11 & 8 & 13 & 32 \\
Moral-Conform & 1 & 0 & 0 & 1 \\
Moral-Select & 3 & 2 & 1 & 6 \\
Moral-Manipulate & 2 & 0 & 1 & 3 \\
Total Moral & 6 & 2 & 2 & 10 \\
Cognitive-Conform & 0 & 0 & 4 & 4 \\
Cognitive-Select & 0 & 0 & 1 & 1 \\
Cognitive-Manipulate & 2 & 0 & 0 & 2 \\
Total Cognitive & 2 & 0 & 5 & 7 \\
\hline
\end{tabular}

gain resources, and they did so primarily by developing an understanding of their constituents and trying to adapt to their needs, as exemplified in the following quotations and listed in detail in Table 4.

'We had a follow up meeting with Mr Nilsson of Sony Ericsson. They are still very much interested in working with us, but need a detailed development plan for our technology. Need to co-ordinate with the researchers for this.' (Burt, 20100422) ${ }^{1}$

'Tested revised version of [our case] and have fed back to [the developer] with a serious issue affecting the PC version. Developer is working on the fix. Met with the informatics department and they presented us with their latest work. We had a long session discussing how we could improve it further and just tonight they sent us their latest revision and it looks really good!' (Matt, 20100305) 
Table 9. Combined case strategy analysis.

\begin{tabular}{lccccc}
\hline & $\begin{array}{l}\text { Image } \\
\text { Enhancement }\end{array}$ & $\begin{array}{l}\text { Music } \\
\text { Training }\end{array}$ & $\begin{array}{l}\text { Jewelry } \\
\text { Design }\end{array}$ & $\begin{array}{l}\text { Napkin } \\
\text { Ads }\end{array}$ & $\begin{array}{c}\text { Total } \\
\text { Pragmatic-Conform }\end{array}$ \\
\hline 11 & 14 & 17 & 9 & 51 \\
Pragmatic-Select & 9 & 11 & 15 & 10 & 45 \\
Pragmatic-Manipulate & 7 & 8 & 9 & 13 & 37 \\
Total Pragmatic & 27 & 33 & 41 & 32 & 133 \\
Moral-Conform & 4 & 6 & 2 & 1 & 13 \\
Moral-Select & 8 & 9 & 15 & 6 & 38 \\
Moral-Manipulate & 7 & 0 & 0 & 3 & 10 \\
Total Moral & 19 & 15 & 17 & 10 & 61 \\
Cognitive-Conform & 10 & 7 & 9 & 4 & 30 \\
Cognitive-Select & 2 & 6 & 4 & 1 & 13 \\
Cognitive-Manipulate & 2 & 0 & 0 & 2 & 4 \\
Total Cognitive & 14 & 13 & 13 & 7 & 47 \\
\hline
\end{tabular}

'Been preparing and holding our third and last board meeting. This meeting was very useful for us as well because we got some good advices regarding our future issues and plans and we now know what we should really focus on like for instance the jewelry manufactures in Sweden instead of China and creating contacts with potential partners. We will also start focusing on the promotion issues for the competition part.' (Maria, 20100409)

Napkin Ads is an exception: due to their relative resource independence and fewer product/service development requirements, they were able to engage more in attempting to influence and change customer needs:

'Once we can see and analyse the results of our first campaign we will have the information and numbers needed to structure a more relevant pricing scheme.' (Jim, 20100326)

'We had the follow-up meeting with [a client] on Thursday. It was quite positive, they accepted our rates and are very interested in offering our service to their clients. They are about to set up a contract. With this cooperation, we hope to be able to expand our network into Malmo, and then Uppsala, Stockholm and Gothenburg.' (Saul, 20100409)

With regard to moral legitimacy, the picture looks quite different. The primary strategy here for all cases was selection through goal formulation in which, to varying degrees, all cases were strongly engaged. The Jewelry Design case had a very strong focus on goal formulation and little focus on moral-conform and moral-manipulative strategies. In the data this is expressed by continuous discussion and reiteration of the company goals, with little concern about and interaction with the external environment:

'I finished writing up some rules to be used on our trial competition. I wrote some extra stuff for the business plan. Our group came up with a rough schedule of we would have to do during this period.'(Jenny, 20100507)

Cognitive legitimacy is the least visible of the three types. This is probably due to methodological challenges. Because cognitive realms often involve taken-for-granted assumptions, of an implicit nature, it is to be expected that writers would not make such assumptions explicit in the diaries to the same extent. In line with theory, conforming is the most used cognitive strategy (Scott, 2014):

'Looked into legal implications of using/referencing Wikipedia in MT. Unfortunately, Wikipedia does not have a legal department as they are an open source community thus blurring the lines as to whether or not we can use them (though I think we can without permission).' (Matt, 20100219)

'LUAP formed Image Enhancement $\mathrm{AB}$ so that we could qualify for the VINN NU grant.' (Burt, 20100414)

In summary, our analysis indicates that in general pragmatic issues hold primacy in the legitimizing strategies of new ventures, and that the ventures engaged in a significant degree of selection concerning which type of moral pressures to conform to by spending considerable effort in goal-setting activities. Cognitive legitimacy remained difficult to observe given 
the method used, but conformity to cognitive pressures appeared to be the primary strategy.

\section{Conclusions}

The area of legitimacy-creating in new ventures has not been widely studied to date due to the challenge of accessing firms prior to their being established. In this article, we report on a study of legitimacy strategies in the very early phases of venture creation, with a fine-grained data set. Our analysis suggests that relative newness of organizational technology leads to an increasing focus on conformity strategies to gain legitimacy (exemplified by Image Enhancement and Music Training). More established technologies (for example, Napkin Ads) enabled a successful engagement with more manipulative strategies. This finding supports the suggestion of Ashforth and Gibbs (1990) that more conformity is necessary when organizational technologies are less mature. This indicates that, in addition to the costs of product development, technological uncertainty and the market uncertainty of a high-technology start-up, new technology-based ventures are also subject to higher costs in conforming to institutional pressures.

We also found that the new ventures analysed were strongly engaged in moral selection strategies in terms of goal formulation. This was clear in all the cases, but noticeable in particular with Jewelry Design. We suggest that this level of fluidity of moral strategy is a unique feature of new organizations, making them an excellent empirical field for the study of moral legitimacy in general, and moral selection in particular (Dowling and Pfeffer, 1975; Oliver, 1991). The focus of the moral selection strategy of the new ventures in this study is not based on the organization 'as is' (Suchman, 1995) but rather on what organization the management team would like to create and/or what they believe is feasible for the organization to become. Our results indicate that the new ventures with relatively low costs could adhere to cognitive legitimacy and moral selection. Because they start with a clean slate, they have relatively low set-up costs. Suchman (1995) describes the very costly process of maintaining and repairing moral legitimacy once it is lost: it seems, rather, that new ventures have a cost advantage when creating moral legitimacy. To use a legal analogy, they are innocent until proven guilty. Manipulation strategies are normally considered to be beyond the scope of new ventures, because they are understood to be resource-intensive (Zimmerman and Zeitz, 2002). However, both pragmatic and moral manipulation strategies are regarded as within the reasonable scope of new ventures (Suchman, 1995); for example, new ventures prove to be credible inventors of new moral standards to an extent that established organizations cannot achieve (Honig et al, 2013).

\section{Practical implications}

The framework suggested in this article provides a strategy toolbox for new entrepreneurs. While most are aware of the need to conform to institutional pressures, they may not think of other, plausible legitimizing strategies. We suggest that new ventures could more consciously devise strategies on how to deal with institutional norms. With regard to policy implications, the article introduces avenues for policy makers to influence and support new venture development. The data indicate the primacy of pragmatic strategies over moral and cognitive ones and so policy could follow this, creating pragmatic incentives for new ventures, supporting them in their legitimization process. The malleability of moral legitimacy in new ventures also provides an interesting possibility for policy. In striving to find the right moral goals and aims, new ventures seem to be more susceptible to being influenced to adopt the 'right' moral direction. In addition, while new ventures may have a disadvantage with respect to conforming to coercive pressures and legal frameworks, they seem to have an advantage in developing moral legitimacy, enabling them to overcome the liabilities of newness as they emerge as established organizations.

\section{Limitations and suggestions for further research}

In line with the theoretical arguments of Zimmerman and Zeitz (2001), we suggest that new venture legitimacy creation is very different from the building, maintenance and repair of legitimacy of established firms. This has important implications for understanding institutional theory in the specific setting of new ventures. However, due to its exploratory nature and the limited amount of cases, the present study would need to be replicated qualitatively as well as tested and proven quantitatively in the new entrepreneurial setting. Comparing a new setting to the setting of an established organization is very challenging because they are qualitatively different entities. However, long longitudinal or retrospective case studies might capture the differences in the legitimacy creation characteristics at an early stage of venture creation and at a later stage. For example, the book The History of IKEA (Kamprad and Torekull, 1998) starts with a description of audacity and how the young entrepreneur wanted to prove someone wrong, 
and ends with the agony of responsibility and the fear of making mistakes.

\section{Notes}

${ }^{1}$ The 8-digit number identifies the date of the journal entry, in each case: thus 'Burt, 20100422' is Burt's journal entry from 22 April 2010.

\section{References}

Aldrich, H.E., and Fiol, M.C. (1994), 'Fools rush in? The institutional context of industry creation', Academy of Management Review, Vol 19, No 4, pp 645-670.

Aldrich, H.E., and Ruef, M. (2006), Organizations Evolving, Sage, London.

Anderson, A.R., Park, J., and Jack, S. (2007), 'Entrepreneurial social capital - conceptualizing social capital in new high-tech firms', International Small Business Journal, Vol 25, No 3, pp 245-272.

Ashforth, B.E., and Gibbs, B.W. (1990), 'The double-edge of organizational legitimation', Organization Science, Vol 1, No 2, pp 177-194.

Barreto, I., and Baden-Fuller, C. (2006), 'To conform or to perform? Mimetic behaviour, legitimacy-based groups and performance consequences', Journal of Management Studies, Vol 43, No 7, pp 1559-1581.

Bird, B., Schjoedt, L., and Baum, J.R. (2012), 'Entrepreneurs' behavior: elucidation and measurement', [editor's introduction], Entrepreneurship Theory and Practice, Vol 36, No 5, pp 889-913.

Bolger, N., Davis, A., and Rafaeli, E. (2003), 'Diary methods: capturing life as it is lived', Annual Review of Psychology, Vol 54, No 1, pp 579-616.

Cassar, G., and Craig, J. (2009), 'An investigation of hindsight bias in nascent venture activity', Journal of Business Venturing, Vol 24, No 2, pp 149-164.

Clarke, J. (2011), 'Revitalizing entrepreneurship: how visual symbols are used in entrepreneurial performances', Journal of Management Studies, Vol 48, No 6, pp 1365-1391.

Cornelissen, J.P., and Clarke, J.S. (2010), 'Imagining and rationalizing opportunities: inductive reasoning and the creation and justification of new ventures', Academy of Management Review, Vol 35, No 4, pp 539-557.

Davidsson, P. (2006), 'Nascent entrepreneurship: empirical studies and developments', Foundations and Trends in Entrepreneurship, Vol 2, No 1, pp 1-76.

De Clercq, D., and Voronov, M. (2009), 'Toward a practice perspective of entrepreneurship: entrepreneurial legitimacy as habitus', International Small Business Journal, Vol 27, No 4, pp 395-419.

DiMaggio, P.J., and Powell, W.W. (1983), 'The iron cage revisited: institutional isomorphism and collective rationality in organizational fields', American Sociological Review, Vol 48, No 2, pp 147-160.

Donnellon, A., Ollila, S., and Williams Middleton, K. (2014), 'Constructing entrepreneurial identity in entrepreneurship education', International Journal of Management Education, Vol 12, No 3, pp 490-499.

Dowling, J., and Pfeffer, J. (1975), 'Organizational legitimacy: social values and organizational behavior', Pacific Sociological Review, Vol 18, No 1, pp 122-136.

Drori, I., and Honig, B. (2013), 'A process model of internal and external legitimacy', Organization Studies, Vol 34, No 3, pp 345-376.

Feyman, Y. (2014), 'Shocking secrets of FDA clinical trials revealed', Forbes, http://www.forbes.com/sites/ theapothecary/2014/01/24/shocking-secrets-of-fda-clinicaltrials-revealed/ (accessed 19 October 2015).
Freeman, J., Carroll, G.R., and Hannan, M.T. (1983), 'The liability of newness: age dependence in organizational death rates', American Sociological Review, Vol 48, No 5, pp 692-710.

Hargadon, A.B., and Douglas, Y. (2001), 'When innovations meet institutions: Edison and the design of the electric light', Administrative Science Quarterly, Vol 46, No 3, pp 476-501.

Haynie, J.M., Shepherd, D.A., and Patzelt, H. (2012), 'Cognitive adaptability and an entrepreneurial task: the role of metacognitive ability and feedback', Entrepreneurship Theory and Practice, Vol 36, No 2, pp 237-265.

Honig, B., Karlsson, T., and Hä gg, G. (2013), 'The blessing of necessity and advantages of newness', Advances in Entrepreneurship, Firm Emergence and Growth, Vol 15, pp 63-94.

Kamprad, I., and Torekull, B. (1998), Historien om IKEA: Ingvar Kamprad berättar för Bertil Torekull:[om ledarskapet, framtiden, det ryska ä ventyret, pengarna, knepen och" den goda kapitalismen"] [in Swedish], Wahlström \& Widstrand, Stokholm.

Landau, D., Drori, I., and Terjesen, S. (2014), 'Multiple legitimacy narratives and planned organizational change', Human Relations, Vol 67, No 11, pp 1321-1345.

Larson, A., and Starr, J.A. (1993), 'A network model of organization formation', Entrepreneurship: Theory and Practice, Vol 17, No 2, pp 5-15.

Lounsbury, M., and Glynn, M.A. (2001), 'Cultural entrepreneurship: stories, legitimacy, and the acquisition of resources', Strategic Management Journal, Vol 22, No 6/7, pp 545-564.

Meyer, J.W., and Rowan, B. (1977), 'Institutionalized organizations: formal structure as myth and ceremony', American Journal of Sociology, Vol 83, No 2, pp 340-363.

Mosey, S., and Wright, M. (2007), 'From human capital to social capital: a longitudinal study of technology-based academic entrepreneurs', Entrepreneurship Theory and Practice, Vol 31, No 6, pp 909-935.

Navis, C., and Glynn, M.A. (2011), 'Legitimate distinctiveness and the entrepreneurial identity: influence on investor judgments of new venture plausibility', Academy of Management Review, Vol 36, No 3, pp 479-499.

Ohly, S., Sonnentag, S., Niessen, C., and Zapf, D. (2010), 'Diary studies in organizational research', Journal of Personnel Psychology, Vol 9, No 2, pp 79-93.

Oliver, C. (1991), 'Strategic responses to institutional processes', Academy of Management Review, Vol 16, No 1, pp 145-179.

Palmås, K., and Von Busch, O. (2006), Abstract Hacktivism The Making of a Hacker Culture, Mute Publishing, London.

Politis, D. (2008), 'Does prior start-up experience matter for entrepreneurs' learning? A comparison between novice and habitual entrepreneurs', Journal of Small Business and Enterprise Development, Vol 15, No 3, pp 472-489.

Sarasvathy,s.d.(2008), Effectuation: Elements of Entrepreneurial Expertise, Edward Elgar, Cheltenham.

Scott, W.R. (2014), Institutions and Organizations: Ideas, Interests and Identities, Sage, Thousand Oaks, CA.

Shepherd, D.A., Douglas, E.J., and Shanley, M. (2000), 'New venture survival: ignorance, external shocks, and risk reduction strategies', Journal of Business Venturing, Vol 15, No 5/6, pp 393-410.

Shepherd, D.A., and Haynie, J.M. (2009), 'Birds of a feather don't always flock together: identity management in entrepreneurship', Journal of Business Venturing, Vol 24, No 4, pp 316-337.

Singh, J.V., Tucker, D.J., and House, R.J. (1986), 'Organizational legitimacy and the liability of newness', Administrative Science Quarterly, Vol 31, No 2, pp 171-193.

Starr, J.A., and Macmillan, I.C. (1990), 'Resource cooptation via social contracting: resource acquisition strategies for new 
ventures', Strategic Management Journal, Vol 11, No 5, pp 79-92.

Stinchcombe, A.J. (1965), 'Social structure and social organization', in March, J.G., ed, Handbook of Organizations, Rand McNally, Chicago, IL.

Stone, A.A., and Shiffman, S. (2002), Capturing momentary, self-report data: a proposal for reporting guidelines', Annals of Behavioral Medicine, Vol 24, No 3, pp 236-243.

Suchman, M.C. (1995), 'Managing legitimacy: strategic and institutional approaches', Academy of Management Review, Vol 20, No 3, pp 571-610.

Suddaby, R., and Royston, G. (2005), 'Rhetorical strategies of legitimacy', Administrative Science Quarterly, Vol 50, No 1, pp 35-67.

Tornikoski, E.T. and Newbert, S.L. (2007), 'Exploring the determinants of organizational emergence: a legitimacy perspective', Journal of Business Venturing, Vol 22, No 2, pp 311-335.

Williams Middleton, K. (2013), 'Becoming entrepreneurial: gaining legitimacy in the nascent phase', International Journal of Entrepreneurial Behaviour and Research, Vol 19, No 4, pp 404-424.

Zaheer, S., Albert, S., and Zaheer, A. (1999), 'Time scales and organizational theory', Academy of Management Review, Vol 24, No 4, pp 725-741.

Zimmerman, M.A., and Zeitz, G.J. (2002), 'Beyond survival: achieving new venture growth by building legitimacy', Academy of Management Review, Vol 27, No 3, pp 414-431.

Zott, C., and Huy, Q.N. (2007), 'How entrepreneurs use symbolic management to acquire resources', Administrative Science Quarterly, Vol 52, No 1, pp 70-105.

\section{Appendix A}

\section{Case characteristics}

\begin{tabular}{|c|c|c|c|c|c|c|c|}
\hline Case & Alias & Country & Age & $\begin{array}{l}\text { Business } \\
\text { model/type }\end{array}$ & Pre-existing network & Diaries & Week 21 \\
\hline Music Training & $\begin{array}{l}\text { Matt } \\
\text { Ron } \\
\text { Sean }\end{array}$ & $\begin{array}{l}\text { Netherlands } \\
\text { Lebanon } \\
\text { Russia }\end{array}$ & $\begin{array}{l}23 \\
30 \\
28\end{array}$ & $\begin{array}{l}\text { Product } \\
\text { development } \\
\text { (software) }\end{array}$ & $\begin{array}{l}\text { University provided idea, } \\
\text { entrepreneurs do not have } \\
\text { existing ties }\end{array}$ & 56 & Active \\
\hline $\begin{array}{l}\text { Image } \\
\text { Enhancement }\end{array}$ & $\begin{array}{l}\text { Burt } \\
\text { Mac } \\
\text { Tony }\end{array}$ & $\begin{array}{l}\text { Canada } \\
\text { US } \\
\text { Poland }\end{array}$ & $\begin{array}{l}28 \\
26 \\
24\end{array}$ & $\begin{array}{l}\text { Product } \\
\text { development } \\
\text { (new technology) }\end{array}$ & $\begin{array}{l}\text { University provided idea, } \\
\text { entrepreneurs do not have } \\
\text { existing ties }\end{array}$ & 41 & Active \\
\hline Napkin Ads & $\begin{array}{l}\text { Jim } \\
\text { Saul } \\
\text { Tom }\end{array}$ & $\begin{array}{l}\text { Australia } \\
\text { Germany } \\
\text { US }\end{array}$ & $\begin{array}{l}24 \\
28 \\
30\end{array}$ & Trading & No & 39 & Active \\
\hline Jewelry Design & $\begin{array}{l}\text { Charlotte } \\
\text { Jenny } \\
\text { Maria }\end{array}$ & $\begin{array}{l}\text { China } \\
\text { Thailand } \\
\text { Sweden }\end{array}$ & $\begin{array}{l}25 \\
25 \\
24\end{array}$ & $\begin{array}{l}\text { Product } \\
\text { development } \\
\text { (customer design) }\end{array}$ & No & 53 & Abandoned \\
\hline
\end{tabular}

